Abstracta Iranica Abstracta Iranica

Revue bibliographique pour le domaine irano-aryen

Volume 22 | 2001

Comptes rendus des publications de 1999

\title{
The Taliban phenomenon. Afghanistan 1994-1997. Oxford University Press, 1999, 288 p.
}

\section{Tchanguiz Pahlavan}

\section{Q OpenEdition}

1 Journals

\section{Édition électronique}

URL : http://journals.openedition.org/abstractairanica/37243

DOI : 10.4000/abstractairanica.37243

ISSN : 1961-960X

Éditeur :

CNRS (UMR 7528 Mondes iraniens et indiens), Éditions de l'IFRI

\section{Édition imprimée}

Date de publication : 15 mai 2001

ISSN : 0240-8910

\section{Référence électronique}

Tchanguiz Pahlavan, «The Taliban phenomenon. Afghanistan 1994-1997. Oxford University Press, 1999, 288 p. », Abstracta Iranica [En ligne], Volume 22 | 2001, document 603, mis en ligne le 17 février 2010, consulté le 09 octobre 2020. URL : http://journals.openedition.org/abstractairanica/37243 ; DOI : https://doi.org/10.4000/abstractairanica.37243

Ce document a été généré automatiquement le 9 octobre 2020.

Tous droits réservés 


\section{The Taliban phenomenon. Afghanistan 1994-1997. Oxford University Press, 1999, 288 p.}

Tchanguiz Pahlavan

1 The author with a military and diplomatic background was also co-editor of a book published under the title: Beyond Afghanistan: US-Pakistan relations, University of California. The present book is consisting of 11 chapters, a conclusion and 6 appendices.

2 Different aspects of the Taliban phenomenon are discussed in this book: genesis, military dimension, drug problem, roles and interests of the other powers, impact on the region are among the subjects discussed in this book.

INDEX

Thèmes : 13.2. Afghanistan

\section{AUTEURS}

TCHANGUIZ PAHLAVAN

Téhéran 